\title{
Utilization of Bactericide Technology for Pollution Control of Acidic Coal Mine Waste
}

\author{
Mingliang Zhang ${ }^{1, a,{ }^{*}, \text { Haixia Wang }}{ }^{1, b}$ \\ ${ }^{1}$ School of Resources and Environment, University of Jinan, China \\ a mlzhangsd@126.com, b21012187@qq.com
}

\begin{abstract}
Keywords: Coal mine waste, sulfur, oxidation, bactericide
\end{abstract}
Abstract. Exposed to air and water, the oxidation of sulfide minerals (e.g. pyrite) in coal mine waste can result in serious environmental problems such as acid mine drainage (AMD). Thiobacillus ferrooxidans is generally regarded as the principal iron-oxidizing bacteria involved in the process of sulfide oxidation. The bactericide technology to inhibit the activity of Thiobacillus ferroxidans can effectively prevent AMD occurence. In the present study, Thiobacillus ferrooxidans was isolated from acidic coal mine waste and its physiological characteristics were studied. Anionic surfactant (sodium dodecyl sulfate, $50 \mathrm{mg} / \mathrm{L}$ ) was confirmed as an effective bactericide to inhibit the activity of Thiobacillus ferroxidans.

\section{Introduction}

Exposed to air and water, coal mine waste can cause serious pollution of the atmosphere, water and soil. Especially, coal mine waste containing high sulfur can produce acid mine drainage (AMD) due to sulfide (pyrite) oxidation. it has led to serious harm to the ecological system of mining area, because of its strong acidity and toxic heavy metals. The generation of AMD involves a series of physical and chemical reactions, and microbial activity is recognized as a critical factor in this process. Thiobacillus ferrooxidans is the principal iron-oxidizing bacteria involved in sulfide oxidation, which can catalyze acid formation by increasing the oxidation rate of pyrite[1]. The prevention of sulfide minerals oxidation is very important to prevent AMD occurrence. For these reasons, it is important to develop novel approaches for efficient control of AMD production. Currently, the prenvention of early sulfide oxidation is the best strategy to control AMD.

To control the acitivity of Thiobacillus ferrooxidans is an effective method to inhibit the oxidation of sulfides, which have been disscussed by many studies. Some bacteria inhibitors (e.g. anionic surfactants, organic acids, and food preservatives) have been extensively studied to control the activity of Thiobacillus ferrooxidans. Kleinmann (1979) concluded that anionic surfactants such as sodium lauryl sulfate (SLS) and alkylbenzene sulfonate (ABS) are the economical and effecitve inhibitors of Thiobacillus ferrooxidans activity at dosages on the order of 25 to $50 \mathrm{mg} / \mathrm{L}[2]$. Sand et al. (2007) concluded that the application of the biocide isothiazolinone reduced the release of heavy metals and sulfate between $5 \%$ and $50 \%$ for different types of mine waste piles [3]. The addition of sodium dodecyl sulphate (SDS) partly reduced the activity and number of metal sulphide oxidizing bacteria but did not kill the bacteria [4]. At low concentrations of the surfactants, they can induce seepage of $\mathrm{H}^{+}$ into the bacteria cell, which can slow ferrous oxidation by decreasing the activity of enzymes. High concentrations of the surfactants will kill the bacteria by causing permanent damage to the enzymes[5-10].

There have been few studies on pollution control of coal mine waste piles using bactericide in china. In this study, anionic surfactant (SDS) was used as bactericide to explore the possibility of inhibiting the activity of Thiobacillus ferrooxidans isolated from acidic coal mine waste piles, in order to provide a basis for its practical application to pollution cotrol of acidic coal mine waste piles in China. 


\section{Materials and Methods}

Isolation and cultivation of Thiobacillus ferrooxidans. A modified $9 \mathrm{~K}$ medium was used in all experiments. The $\mathrm{pH}$ of medium was adjusted to be 2.5. All incubations were carried out in $250 \mathrm{~mL}$ flasks at $30^{\circ} \mathrm{C}$. All chemicals were analytical grade, and solutions were prepared with sterile deionized water. After the cultivation of the bacteria, spread plate method was used for the separation and purification of bacteria, and finally the bacteria with active metabolism was selected for the following test.

Effect of anionic surfactant (SDS) on Thiobacillus ferrooxidans growth. In order to evaluate the feasibility of anionic surfactant (SDS) inhibiting activity of Thiobacillus ferrooxidans, two batch tests were conducted in flasks: (1) $150 \mathrm{~mL}$ sterile medium (9K medium) incluated with 5\% Thiobacillus ferrooxidans; (2) $150 \mathrm{~mL}$ sterile medium (9K medium) incluated with 5\% Thiobacillus ferrooxidans, and the concentration of sodium dodecyl sulphate (SDS) in the medium was $50 \mathrm{mg} / \mathrm{L}$. the batch tests were performed at $30^{\circ} \mathrm{C}$ in a biochemical incubator and $\mathrm{pH}, \mathrm{Eh}, \mathrm{Fe}^{2+}$ were monitored every 2 days. Thiobacillus ferrooxidans is autotrophic microorganisms, depending on the oxidation of $\mathrm{Fe}^{2+}$ into $\mathrm{Fe}^{3+}$ to obtain energy. The inhibition effect of bactericide can be evaluated by the concentration variation of $\mathrm{Fe}^{2+}$. The concentration of $\mathrm{Fe}^{2+}$ was measured by Phenanthroline spectrophotometric method, and $\mathrm{OD}_{600}$ was measured by spectrophotometric method.

\section{Results and Discussions}

Morphological characteristics. The pure Thiobacillus ferrooxidans was cultivated through the liquid enrichment culture and spread plate method three times. The experiment showed that the circular bacteria colony was formed in solid medium, with a diameter of about 1-2 mm, yellow brown, hard texture, and central projection (Fig.1). Cell size was $0.5 \mu \mathrm{m} \times 2 \mu \mathrm{m}$ through microscope observation.
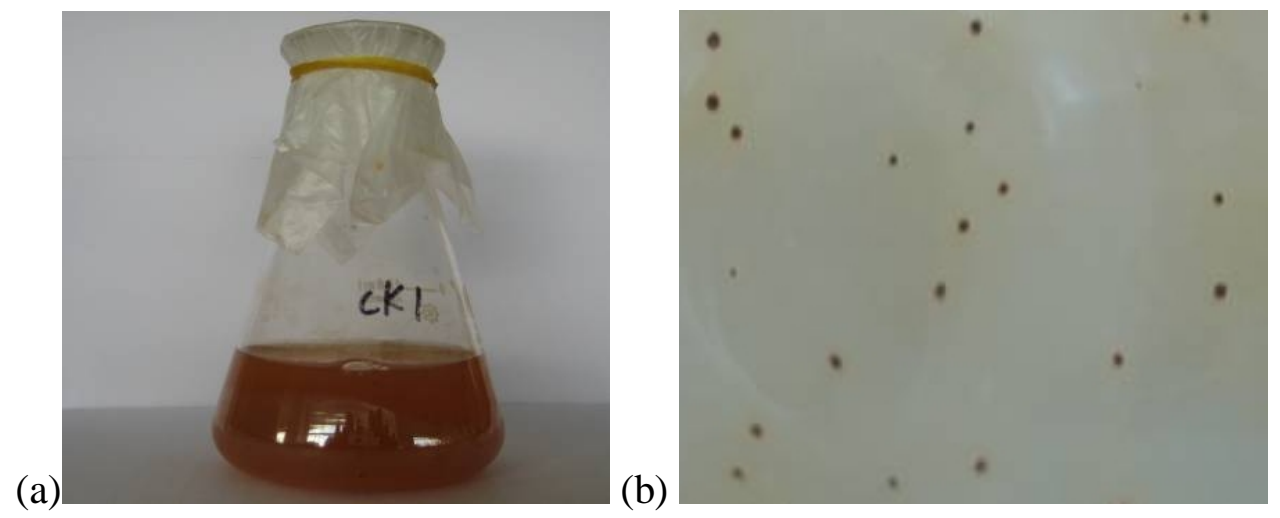

Fig.1 Liquid enrichment culture (a), colony in solid medium (b)

Growth curve of bacteria. The growth curve of Thiobacillus ferrooxidans is shown in Fig.2. In the adaptation period $(0-24 \mathrm{~h})$, the bacteria number was very few with slow increasing, and the oxidation rate of $\mathrm{Fe}^{2+}$ was less than $10 \%$. During the exponential growth period (24-48h), the number of bacteria and $\mathrm{Fe}^{2+}$ oxidation rate increased rapidly. After $48 \mathrm{~h}$, the bacteria growth rate began to slow down and enter the decay period. The number of bacteria can reach up to about $10^{8}$, and the oxidation rate reached $90 \%$. 


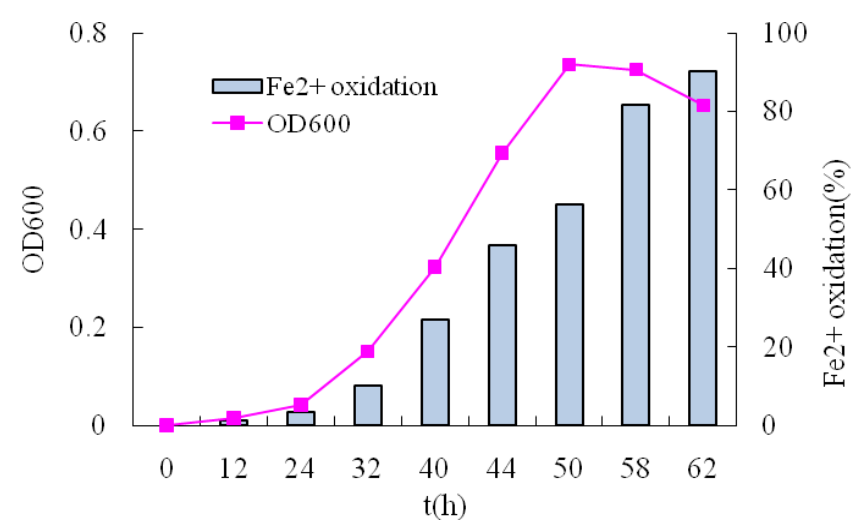

Fig.2 Growth curve of the bacteria

Effect of $\boldsymbol{p H}$. The growth of bacteris under different $\mathrm{pH}$ values is shown in Fig.3. As can be seen from the figure, the suitable $\mathrm{pH}$ value of the bacterial growth was in the range of 2-4. The bacteria had the most vigorous growth and the strongest metabolic capacity in $\mathrm{pH} 2.41$, and iron oxidation rate was $56 \%$ at $48 \mathrm{~h}$, and the $\mathrm{OD}_{600}$ was the highest.

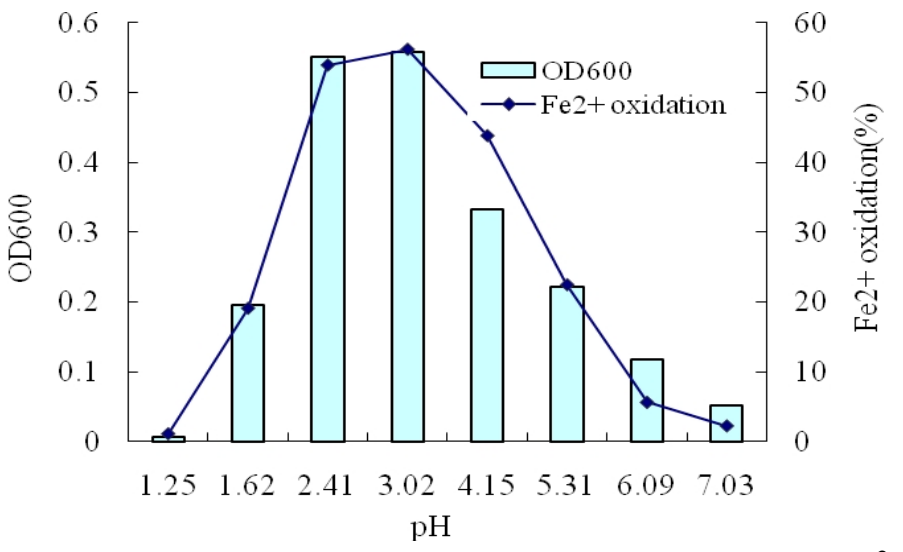

Fig.3 Effect of $\mathrm{pH}$ value on bacteria growth and oxidation of $\mathrm{Fe}^{2+}$ at 48 hour

Effect of temperature. When the ambient temperature increases in the appropriate range, the growth and metabolism of the bacteria will gradually increase. More than the critical temperature, the metabolic activity of the bacteria will decline sharply. The effect of temperature on the bacteria growth is shown in Fig.4. Thiobacillus ferrooxidans was suitable to grow in the temperature $25-35^{\circ} \mathrm{Cwith}$ high oxidation ratio of $\mathrm{Fe}^{2+}(51 \%)$ at $48 \mathrm{~h}$.

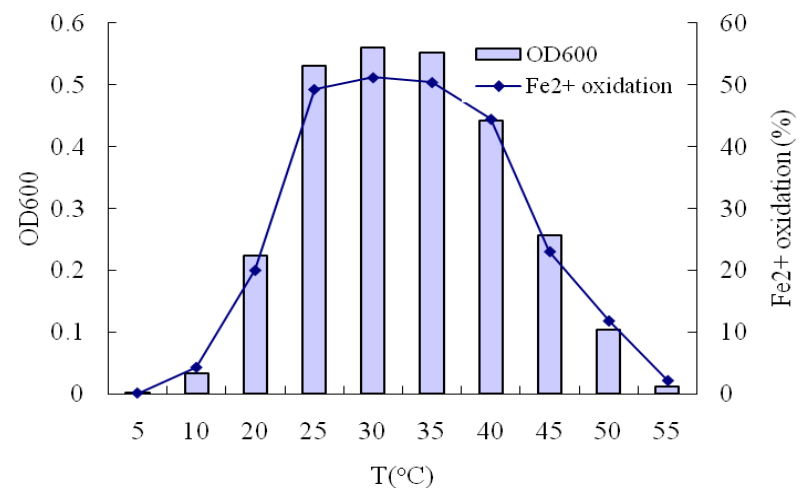

Fig. 4 Effect of temperature on bacteria growth and oxidation of $\mathrm{Fe}^{2+}$ at 48 hour 
Effect of anionic surfactant (SDS) on Thiobacillus ferrooxidans growth. Fig. 5 shows that the concentration of $\mathrm{Fe}^{2+}$ decreased from $8.9 \mathrm{~g} / \mathrm{L}$ to $0 \mathrm{~g} / \mathrm{L}$ for the control treatment (no bactericide), and the solution color changed from light green to red brown, because $\mathrm{Fe}^{2+}$ was oxidized to $\mathrm{Fe}^{3+}$ with the metabolism of Thiobacillus ferrooxidans. It demonstrated Thiobacillus ferrooxidans grew well and multiplied. While, the concentration of $\mathrm{Fe}^{2+}$ decreased very slowly from $8.9 \mathrm{~g} / \mathrm{L}$ to $6.8 \mathrm{~g} / \mathrm{L}$ for the bactericide (SDS) treatment, and the Eh value had no significant change. It showed that SDS (50 $\mathrm{mg} / \mathrm{L}$ ) was the effecitve inhibitor of Thiobacillus ferrooxidans activity.

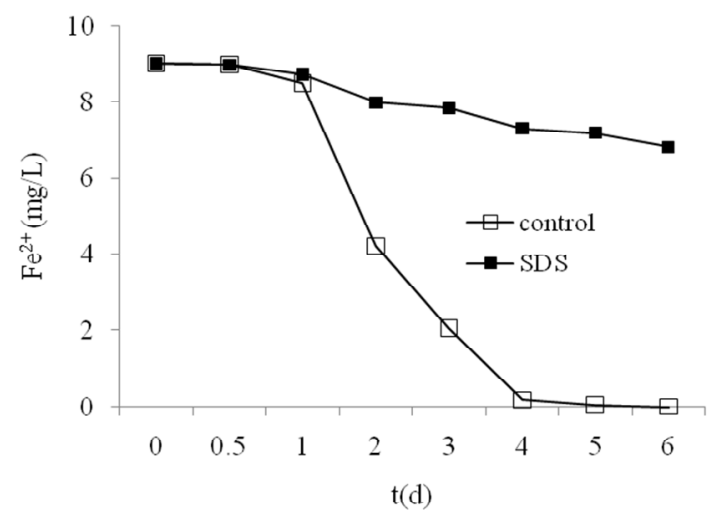

Fig. 5 The variation of $\mathrm{Fe}(\mathrm{II})$ concentration in different treatments

\section{Conclusions}

A strain of Thiobacillus ferrooxidans was isolated from acidic coal mine waste and its physiological characteristics and environmental factors for growth, such as cultivation time, temperature, and $\mathrm{pH}$ were studied. The results showed that the bacteria were suitable to grow in the environment with $\mathrm{pH}$ 2.0-2.5, temperature $30^{\circ} \mathrm{C}$. Sodium dodecyl sulfate $(50 \mathrm{mg} / \mathrm{L})$ was effective bactericide which could inhibit the activity of Thiobacillus ferroxidans.

\section{Acknowledgement}

This research was supported by Shandong Provincial Key Research and Development Program (2015GSF117014).

\section{References}

[1] K. Nyavor, N.O. Egiebor, P.M. Fedorak: Sci Total Environ.Vol. 182 (1996), p. 75-83.

[2] R. L. P.Kleinmann, D. A. Crerar: Geomicrobiol J. Vol.1 (1979), p. 373-388.

[3] W.Sand, P.G.Jozsa, Z.M. Kovacs, et al: J. Geochem.Explor. Vol. 92(2007), p. 205-211.

[4] A. Peppas, K. Komnitsas, I.Halikia. Miner. Eng. Vol.13(2000), p.563-574.

[5] V. Rastogi: Miner. Eng. Vol. 48 (1996), p.66-71.

[6] G.Singh, M.M. Bhatnagar: Mine Water Environ. Vol. 7(1988), p.13-25.

[7] P.R Dugan: Biotechnol. Bioeng. Vol. 29 (1987), p. 49-54.

[8] R.Coulton, C.Bullen, J.Dolan, C. Hallet, J.Wright, C.Marsden: Land Contam Reclamat. Vol.11 (2003), p.245- 52.

[9] S.G.Benner, D.W.Blowes, C.J.Ptacek, K.U.Mayer: Appl. Geochem. Vol.17 (2002), p.301-320. [10] P.R.Dugan, W.A.Apel: Appl Environ Microbiol.Vol.46 (1983), p. 279-282. 